\title{
The Effects of Structural Design on Ventilation of Buildings in Ghana and Its Effect on Transmission of Infectious Diseases
}

\author{
Samuel Kafui Awuku, Deling Wang* \\ School of Urban Construction, Yangtze University, Jingzhou, China \\ Email: *awukusamuel@gmail.com
}

How to cite this paper: Awuku, S.K. and Wang, D.L. (2020) The Effects of Structural Design on Ventilation of Buildings in Ghana and Its Effect on Transmission of Infectious Diseases. Open Access Library Journal, 7: e6842.

https://doi.org/10.4236/oalib.1106842

Received: September 20, 2020

Accepted: October 27, 2020

Published: October 30, 2020

Copyright () 2020 by author(s) and Open Access Library Inc.

This work is licensed under the Creative Commons Attribution International License (CC BY 4.0).

http://creativecommons.org/licenses/by/4.0/

\begin{abstract}
The physical design of buildings is an essential component of its infection control measure to minimize the risk of transmission of any infectious disease. Many buildings in Ghana have poorly designed ventilation systems for various uses. To this end, a survey was conducted in the Sunyani Municipality to investigate how ventilation designs help to prevent infectious diseases. In this study, buildings within the Sunyani municipality were assessed for the type of ventilation system(s) used, ventilation routes such as the number of exits, the materials used for buildings, history of infectious diseases and the effects of these building specifications on the incidence and spread infectious diseases. Findings of the study indicated that Ghana's Building Code regulation on ventilation design was not used by majority of building owners and builders (including masons, engineers etc.) alike. Poor ventilation was as a result of change and/or modification in the original use of the buildings as designed. The study concludes that data on ventilation design of the buildings did not provide the full evidence as solely responsible for occurrence and transmission of diseases. However, it could be a predisposing factor for the spread of diseases especially infectious diseases. The study recommends among other things that builders and designers should consider the use of green materials such as bamboos and plant based building materials which absorb and transmit less heat to ensure thermal comfort of buildings.
\end{abstract}

\section{Subject Areas}

Architecture

\section{Keywords}

Ventilation, Building, Ventilation Design, Thermal Comfort, Infectious

Disease, Indoor, Air, Occupants, Prevention, Transmission, Ghana, Sunyani 


\section{Introduction}

In present day culture, people spend over $90 \%$ of their time indoors [1]. For this reason, indoor climate and/or condition become fundamental to the comfort and health of occupants. In a residential building, daily activities contaminate the ambient air with odors, carbon dioxide and water vapor. To ensure the healthiness of the environment and to avoid the formation of pollutants, toxicity or allergens, it is necessary to dilute the concentration of the pollutants dispersed into volumes of indoor air through the air exchange by means of ventilation [2].

Studies such as Gao, et al. [3]; Awbi [4]; Khaleghi [5] have argued that diseases may be transmitted rapidly the airborne route in the indoor environment. Several factors in the indoor climatic factors have been reported to cause health challenges, such as noise, thermal climate, light, but poor indoor air quality is often the most critical one. These studies observed that the use of ventilation prevention strategy or intervention reduces the chance of transmission of infection by pointing the flow of airborne infectious agents away from susceptible persons and/or by removing infectious agents from room air. However, these studies did not take into account the other external factors that could be precursors that influenced the indoor climatic conditions of the buildings under study. Again, the health histories of the occupants were not highlighted in the study. Some did not also take into account the indoor activities and/or use which could also serve as grounds for development of disease causing pathogens and hence spread of infectious diseases.

According to Jenkins [6] in any building design, ventilation is a critical component in ensuring thermal and human comfort. Poor ventilation design in buildings can be well understood in the context of human morphology. Ventilation components in buildings such as windows, exhausts and ventilation ducts and air passages, serve as the respiratory organs and passages for buildings. A major determinant of transmission is room ventilation with fresh air, which serves to dilute the concentration of airborne infectious particles. Room ventilation may be provided by mechanical ventilation systems that may also deliver negative pressure [7].

Naturally, ventilated buildings depend on the design of the building form and the building envelope components to control indoor environmental conditions [8]. The physical design of buildings is an essential component of its infection control measure to minimize the risk of transmission of any infectious disease. Thus, it is must be a prerequisite to take into consideration from the initial conception and planning stages of the building [9]. Faults in building design place a heavy burden on the building for the rest of its life and there is no compensation for it. In such situations, the responsibility falls on the shoulders of the designer in that they must think carefully with full concentration and consideration towards completion of their design project [10].

According to Edwards [8], medical experts have raised concerns over the quality of air in indoor environments. This calls for the consideration of con- 
struction of ventilation systems for public buildings such as hospitals, churches, theatres, meeting halls, homes among others. In this regard, there have been proposals for the improvement of building designs and even the construction of buildings by medical practitioners themselves. This is against the backdrop that fresh air and sunlight penetration in buildings can influence the transmission of airborne pathogens. Infections caught inside buildings are a major global cause of sickness and mortality. Understanding how infections spread is pivotal to public health yet current knowledge of indoor transmission remains poor. Before the advent of antibiotics, ventilation and natural light were considered to be an important safety net against infection [11].

\subsection{Problem Statement and Justification}

A conducive indoor environment involves a combination of several factors such as optimal temperature range, absence of odour and other pollutants, lower levels of noise and suitable lighting [12]. Ventilation of residential buildings primarily serves two purposes of eliminating or diluting contaminants, odors and/or moisture to ensure proper indoor air quality, and providing a thermally-comfortable indoor environment. Both objectives contribute to sustain a healthy and comfortable environment for its occupant(s). To achieve comfort, it is important to have the right indoor climate because it reduces the number of infections, number of detected sick building syndrome symptoms, improves productivity and improves sense of comfort. Acceptable air quality is achieved by providing ventilation that will control known and specifiable pollutants to acceptable concentration levels. The quantity of airflow entering and exiting a building depends on the size and location of airflow openings and on the magnitude of stacks, wind and mechanically induced pressure differences [8].

Majority of microbes that cause airborne infections cannot tolerate sunlight, oxidants or the temperature extremes that occur outdoors. Ventilation is arguably more relevant regarding malicious dispersal of toxic chemicals or biological agents. Thus, building ventilation may be an effective strategy for reducing the spread of infectious diseases in indoor environments [11].

According to the Commission for Occupational Safety and Health [13], safe design should be based on the principle that every occupant of a building or structure has a right to be protected from preventable risk of injury or harm. It involves eliminating occupational safety and health hazards at the design stage or controlling risks, as early as possible, in the planning and design of buildings, structures, processes or systems. Building designs therefore should explicitly as far as practicable be able to eliminate or control hazards during the construction phase and use and occupation of a building or structure.

Faulty building designs and attendant problems are a global challenge that can be seen in both developed and developing countries. The most complex design of a building starts from the single stroke of designer. Errors in design can, however, result in discomfort in habitability and unplanned maintenance where 
the designer fails to understand the buildability of that initial concept. The designer who is aware of the risk is more likely to create buildings that will require only planned care [10]. In many countries across the globe, especially in the advanced world, building design codes and guidelines have been provided for buildings of various uses. Against this backdrop, various principles and/or systems are instituted to ensure that inhabitable buildings are safe in relation to the transmission of infectious diseases. As noted by Memarzadeh [14], majority of studies to evaluate the role of ventilation in transmission and control of infectious diseases have been either observational or based on animal models that are not principally related to human diseases. In similar regard, limited studies have been conducted in the areas of the role that building designs play in ensuring adequate ventilation and its attendant role in prevention of infectious diseases in Ghana, hence, the imperativeness of this study in the Sunyani Municipality.

\subsection{Objectives}

1) Determine the structural designs, codes or guidelines that ensure ventilation of buildings in Ghana.

2) Identify the infectious disease risks associated with ventilation designs of buildings in Ghana.

3) Assess the effects of ventilation design on the incidence and transmission of infectious diseases in the Sunyani Municipality.

\section{Literature Review}

\subsection{The Concept of Ventilation}

The model of ventilation has been described by various authors. Nevertheless, the central theme of the argument is focused on the introduction and removal of air in and out of an enclosed environment. For instance, Wikipedia Encyclopedia defines ventilation as the intentional introduction of ambient air into a space and is mainly used to control indoor air quality by diluting and displacing indoor pollutants; it can also be used for purposes of thermal comfort or dehumidification.

Reshetniak [12] described ventilation as a system which supplies clean air into lodging rooms and removes unclean air from lodging rooms. There are several types of ventilation systems in common use, which includes natural exhaust ventilation, natural ventilation boosted with a cooker hood, mechanical exhaust ventilation, mechanical exhaust ventilation boosted with a cooker hood, mechanical supply and exhaust air ventilation system equipped with heat recovery, ventilation combined with air heating system.

\subsection{Types/Systems of Ventilation}

Ventilation could be classified as natural, mechanical and/or hybrid [15]. Natural ventilation involves the deliberate passive flow of sub-aerial air into a structure through planned openings (such as doors, louvers, and windows). Mechan- 
ical ventilation on the other hand uses fans to drive the flow of sub-aerial air into a building. This may be achieved by pressurization (in the case of positively pressurized buildings), or by depressurization (in the case of exhaust ventilation systems) [16]. The mixed mode or hybrid ventilation systems use both natural and mechanical processes.

Jenkins [6] opines that mechanical ventilation system design uses man-made devices to create the effect of natural ventilation to a greater extent. Compared to natural ventilation, the form of airflow control is preferred in spaces that have to deal with more extreme external factors like humidity. Mechanical ventilation model is generally required to ensure the necessary of comfort can be maintained.

According to Walker [17], natural ventilation, uses the normal forces of wind and buoyancy to deliver fresh air into buildings. Thus, air is supplied and/or extracted to and from indoor environments through organic airflow by hitching the power of air pressure differences from natural forces defined by two varieties: buoyancy-driven and wind-driven. This system relies on pressure differences to move fresh air through the structure.

\subsection{Ventilation Design Modules for Buildings}

The recent industrial revolution has culminated in more buildings with a higher percentage of the working population housed indoors over longer periods of time on a daily basis [18]. Against this backdrop, coupled with the effects of climate change and/or global warming, the quality of air in the indoor environment is very critical to life. To ensure quality indoor air, conscious efforts must be made to reduce the concentration of carbon resulting from heat in the indoor environment. Residential buildings in humid areas could lower the carbon emissions by the introduction of a structural design that could maintain indoor comfort temperatures without using any mechanical equipment [19]. Khaleghi, et al. [5] identified four key elements of a building that come together to form the indoor environment. These include structure (including the windows in the building envelope), the heating, ventilation and air-conditioning (HVAC) concept/system, the outdoor environment and the occupants' activities.

\subsection{Concept of Building and Building Designs}

Building design is both a structured and innovative process where the spaces identified in the building program are configured in a building that has structure, circulation, services, form, and aesthetics. While engineers may endeavor to design with distinctiveness and importance, the methods of design are also dependent on the impact of other building genotypes and their own past practices and methods of design [20].

\subsection{Factors to Consider in Building Ventilation Designs}

The design and planning of buildings and/or a community is critical in ensuring 
adequate ventilation. Most aerial infections occur primarily in indoor environments, where over $90 \%$ of modern day people spend their time [1]. Three common factors associated with indoor distress and morbid environment in residential buildings are high air temperature, high air pollution and low air movement. The high air temperature result from urban heat island effects, combination of direct solar radiation, diffused radiation from the sky dome and reflected radiation from both adjacent buildings and hard surfaces. This increased heat penetrates into indoor spaces through convection, conduction and radiation mechanisms [21].

Ventilation rates and outdoor air requirements differ significantly, depending on the design and function of the building, the occupancy rate among others [22]. Rajkumar [18] posits that the introduction of quality air into the indoor environment is affected by factors such as poor architecture, poor maintenance, unregulated modification and sub-optimal operations of the buildings concerned. For instance, Rajkumar observed that the design of a building and its ventilation system can affect the comfort of the occupants and consequently the indoor air quality. Hence, buildings should be constructed with special consideration of the size of spaces to be served, number of occupants, use, and any special use of the areas adjacent areas within the same building. The design system of the building and its ventilation system must allow for all pollutants generated within the building or catchment area to be expelled. Due to the growing demand for space and accommodation, people have renovated many buildings, unfortunately without paying enough attention to the indoor climate. The effectiveness of a ventilation system can be gauged through an appraisal of environmental factors such as the quality of air supplied, the thermal comfort conditions of the space and the level of airborne impurities within the space.

\subsection{Concept of Infection and Infectious Diseases}

Infectious diseases are caused or enhanced by a number of factors which include but not limited climate, social, environmental factors. For example, NASA [23] catalogued a number of factors that influence or enhance the occurrence of infectious diseases. The report noted that noise, thermal climate, light and indoor climate may cause health problems, but poor indoor air quality is often the most critical one. Climate change plays an important role in infectious disease occurrence which leads to an apparent increase in many infectious diseases. A warming and unstable climate plays an ever-increasing role in driving the global emergence, resurgence and redistribution of infectious diseases.

Infectious diseases are normally transmitted based on certain physiognomies and spread through populations in predictable ways. Thus, these diseases can be spread from a single source referred to as point source such as an individual with active infection or in an ongoing way, in a person-to-person pattern [24]. Infectious diseases are transmitted through three primary routes. First, through direct contact and fomites which are non-living objects that transport infectious or- 
ganisms from one individual to another. Secondly, large droplets (generally with a mass median aerodynamic diameter (MMAD) of $>10 \mu \mathrm{m}$ ); and thirdly, particles with MMAD $<10 \mu \mathrm{m}$ sometimes termed droplet nuclei. Large droplets are those larger than $5-100 \mu \mathrm{m}$ at the original time of release [25].

According to Memarzadeh [14], it is widely assumed that infectious diseases are spread through airborne routes that are associated with natural or mechanically created air flows. This assumption is innately weak because in addition to the complexity of airborne transmission, strong evidence suggests that infection transmission may occur by means of other routes. Transmission of infectious particles may occur through a ventilation system, but there are clear incidents of transmission from water reservoirs or particle settling on surfaces and being acted upon by the surrounding atmosphere via hydro and hygroscopic factors temperature and relative humidity and dust. The infectious agent may also undergo a physical change caused by evaporation, dehydration, rehydration, effects of UV light, or any number of other physical parameters.

\subsection{Role of Ventilation Building Designs in Transmission/Prevention Infectious Diseases}

The WHO study of 2009 identified that many variables can influence disease transmission and the possible interactions that affect a pathogen's ability to be transmitted or to remain viable and virulent. These included but not limited to necessary infecting dose, susceptibility of the host, infectivity of the pathogen, and environmental factors [26]. This means that the relationship between air changes per hour $(\mathrm{ACH})$ and infection transmission, in a closed environment or outdoors, is quite perplexing. The enigma of disease transmission is further convoluted by the mode(s) of transmission, the physical mechanisms of transmission, individual behaviors, and the lack of evidence for the effect of spatial and particle dispersion factors [14].

Ventilation systems are nevertheless designed to meet health, comfort and energy requirements [27]. Studies have shown that transmission through direct contact, large droplets $>10 \mathrm{~m}$ and droplet nuclei $<10 \mathrm{~m}$ cannot be influenced by ventilation. Control strategies for large droplet transmission include respiratory hygiene of coughing into handkerchiefs or tissue paper or putting masks to prevent dissemination of particles [28]. Because such particles are quite heavy and drop quickly, general dilution and even enclosures and exhaust ventilation will not expressively influence airborne particle concentrations and the potential for transmission. Although some of the moisture content may evaporate, it does not happen fast enough to change large droplets into droplet nuclei, especially as $95 \%$ of the content must evaporate for the MMAD to decrease by $50 \%$. Droplet nuclei particles may be transported through ventilation systems, as has been documented for tuberculosis, Q-fever, and measles [29].

If influenza transmission occurs not only through direct contact or large droplets, as is the established public health convention, but also through the airborne 
route, as modern statistics suggest, heating, ventilating, and air-conditioning (HVAC) systems may contribute far more to both transmission of disease and, potentially, the reduction of transmission risk. Notwithstanding, ventilation represents a primary infectious disease control strategy through dilution of room air around a source [30]. Directed supply and/or exhaust ventilation such as laminar flow and transposition is important in numerous environments [31].

Spengler et al. [32] argued that modern buildings not only tend to be sophisticated, they also contain various sources of indoor air pollutants. Having inherited design features that are not favourable for preventing the spread of airborne contaminants, many modern-day buildings such as hospitals are therefore primary examples of facilities caught in the indoor air quality crisis. The infection hazards have not only strained the design and operation of ventilation systems, but have also called into question the architectural design of rooms or spaces of occupation [33].

In a study conducted by Memarzadeh and $\mathrm{Xu}$ [34] which discussed the significance of employing scientific enquiry to disease transmission and designing a ventilation system based on a site-specific risk analysis. The study concluded that many factors influence disease transmission and that a ventilation system based on a comprehensive risk assessment can reduce infection risk without necessarily increasing ventilation airflow rate. This however is in contradiction to the findings of $\mathrm{Li}$ et al. [29] who asserted that there was empirical evidence to suggest a correlation between ventilation and air movements in buildings and the transmission and spread of infectious diseases such as measles, Mycobacterium tuberculosis (M. tb), chickenpox (varicella), influenza, smallpox, and severe acute respiratory syndrome (SARS). This is confirmed by Memarzadeh [14], that building ventilation systems help to prevent building-associated diseases by attenuating and removing unknown airborne microbial contaminants.

\section{Research Methodology}

A descriptive survey was employed as the study design. This design afforded the researcher to use methods in positivist paradigm research to seek to explain and predict the relationship between constituent parts of a phenomenon in order to achieve systematic observation, interviewing and questioning through predetermined research questions with the aim of providing standardization and consistency.

The population of the study was residents of the Sunyani Municipality. The target population was occupants of residential and commercial buildings in the municipality. Others also included architects and draughtsman, civil engineers and masons, and health workers. These professionals were consulted to solicit information on the kinds of structural ventilation designs, building codes and guidelines used for buildings in Ghana, and the infectious diseases associated with such designs respectively.

Purposive and simple random sampling techniques were applied to select two 
hundred and thirty (230) respondents for the study. This included five (5) each of architects, masons, draughtsman, civil engineers and health workers who were purposively sampled as two hundred (200) occupants or users of buildings in the Sunyani Municipality who were randomly sampled.

Data was collected from both primary and secondly sources using structured questionnaire and direct observation. That is, the primary data was obtained from the answered questionnaires, while the secondary data was obtained from building code and guidelines, health records and other organizational process assets related to the study from both print and electronic sources. The primary data collected from the survey were analyzed using Microsoft Excel spreadsheet and Statistical Package for Social Scientists (SPSS) computer softwares. This helped to organize the data into graphical representation such as tables, bar or pie charts among others. The SPSS was used to calculate means, mode, median, standard deviations among others.

\section{Results and Discussion}

\subsection{Results}

\subsubsection{Demography of Respondents}

Table 1 presents the personal background information of the respondents used in the study. Amongst the features relevant to this study that were assessed included the gender, age, and occupation.

As illustrated in Table 1 below, the gender distribution of respondents revealed that males were more accounting for $56.1 \%$ while their female counterparts accounted for the remaining $43.9 \%$. Though the female population in ghana outweighs that of the male sect, male participation in the study was high due to the fact that many women often shy away from being included in such research works. With respect to age, it was revealed that majority (37.8\%) of the respondents were of the ages of $36-45$ years. This was followed by $26-35$ years (26.1\%), 46 - 60 years (18.3\%), 18 - 25 years (10.0\%) and the least of $7.8 \%$ being above 60 years. This indicates that the population is generally youthful and in their active life stage. The results of the study inicated that majority of the residents of the Sunyani Municipality were traders representing 30.9\%. This was followed by civil servants being $17.8 \%$ and the least of $0.4 \%$ being a clergyman.

\subsubsection{Structural Designs, Codes or Guidelines that Ensure Ventilation of Buildings in Ghana}

As illustrated in Figure 1, majority (60.5\%) of the buildings in the Sunyani municipality were residential facilities while the remaining $39.5 \%$ of the buildings were for commercial purposes. These include offices and facilities used by small, medium to large scale commercial institutions.

An assesment of the dimensions of rooms of buildings occupied by respondents revealed that most of the rooms were $12 * 12 \mathrm{ft}$ which represented $28.5 \%$ of the responses. This was followed by $14 * 14 \mathrm{ft}$ and $12 * 14 \mathrm{ft}$ which accounted for $20.5 \%$ and $15.5 \%$ respectively. These dimensions are considered as the normal 
dimensions for a single room and were largely recorded by residential buildings with few commercial rooms which hitherto were used for residential purposes. The least of the dimensions of buildings was over $18{ }^{*} 18 \mathrm{ft}$ which was recorded by commercial buildings. This is depicted in Figure 2 .

The occupancy rate of buildings was incumbent on the use of the said buildings (Figure 3). It was revealed that residential buildings had fewer occupants as compared to commercial buildings. It was observed that an occupancy of 1 - 2 persons per room was the highest recorded representing $45.5 \%$. This was followed by 3 - 5 occupancy (33.5\%), 8 - $10(8.5 \%)$, above $10(7.5 \%)$ and the least of $6-7$ occupancy accounting for $5.0 \%$.

Table 1. Demographic characteristics of respondents.

\begin{tabular}{|c|c|c|}
\hline Gender & Frequency (n) & Percentage Frequency (\%) \\
\hline Male & 129 & 56.1 \\
\hline Female & 101 & 43.9 \\
\hline Total & 230 & 100.0 \\
\hline Age (Years) & Frequency (n) & Percentage Frequency (\%) \\
\hline $18-25$ & 23 & 10.0 \\
\hline $26-35$ & 60 & 26.1 \\
\hline $36-45$ & 87 & 37.8 \\
\hline $46-60$ & 42 & 18.3 \\
\hline Above 60 & 18 & 7.8 \\
\hline Total & 230 & 100.0 \\
\hline Occupation & Frequency (n) & Percentage Frequency (\%) \\
\hline Security service personnel & 3 & 1.3 \\
\hline Trader & 71 & 30.9 \\
\hline Farmer & 13 & 5.7 \\
\hline Civil servant & 41 & 17.8 \\
\hline Artisan & 39 & 17.0 \\
\hline Student & 13 & 5.7 \\
\hline Architect & 5 & 2.2 \\
\hline Health worker & 10 & 4.3 \\
\hline Draughtsman & 5 & 2.2 \\
\hline Civil engineer & 5 & 2.2 \\
\hline Clergy & 1 & 0.4 \\
\hline Mason & 5 & 2.2 \\
\hline Banker & 2 & 0.9 \\
\hline Food vendor & 7 & 3.0 \\
\hline Other & 10 & 4.3 \\
\hline Total & 230 & 100.0 \\
\hline
\end{tabular}

Source: Survey, 2020. 


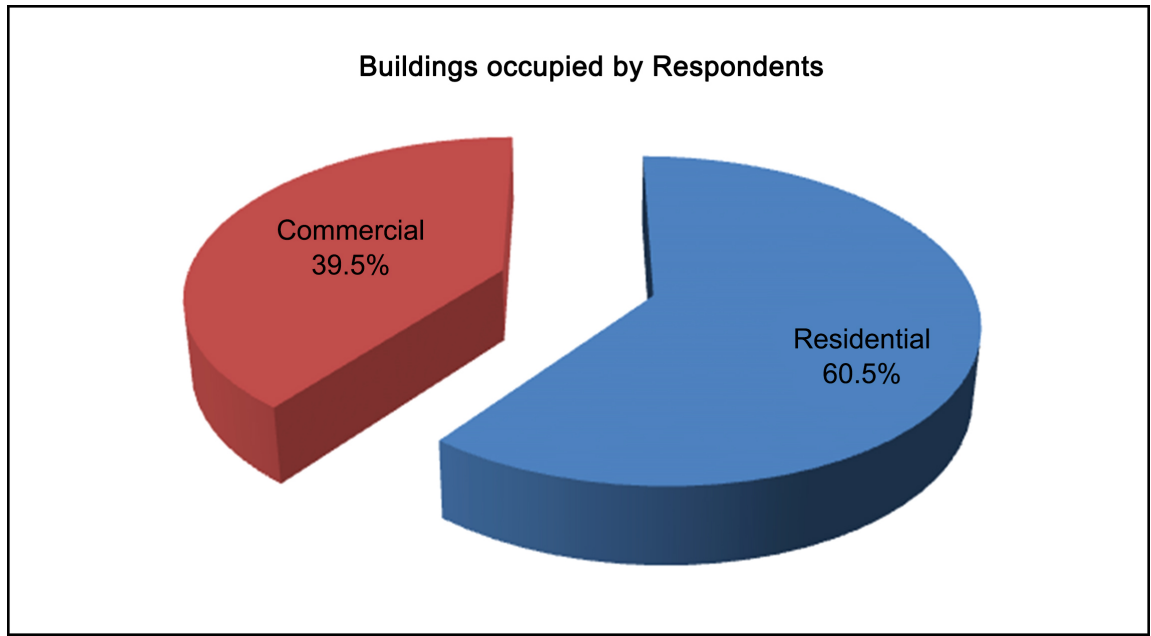

Figure 1. Buildings occupied by respondents (Source: Field Survey, 2020).

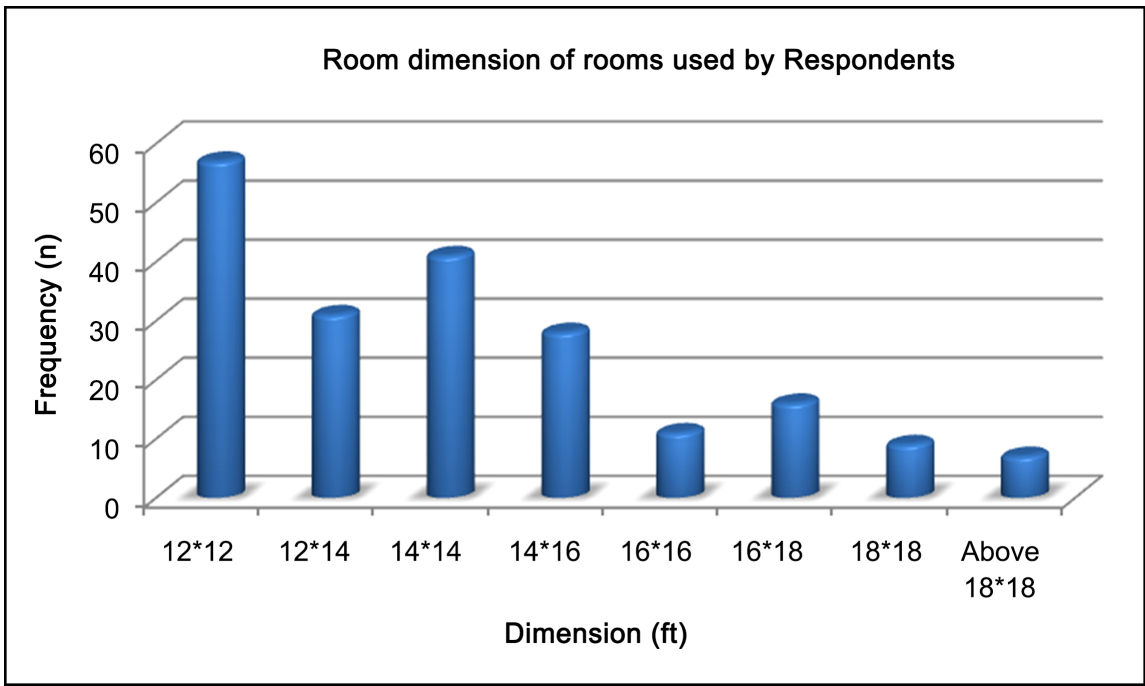

Figure 2. Dimension of rooms used by respondents.

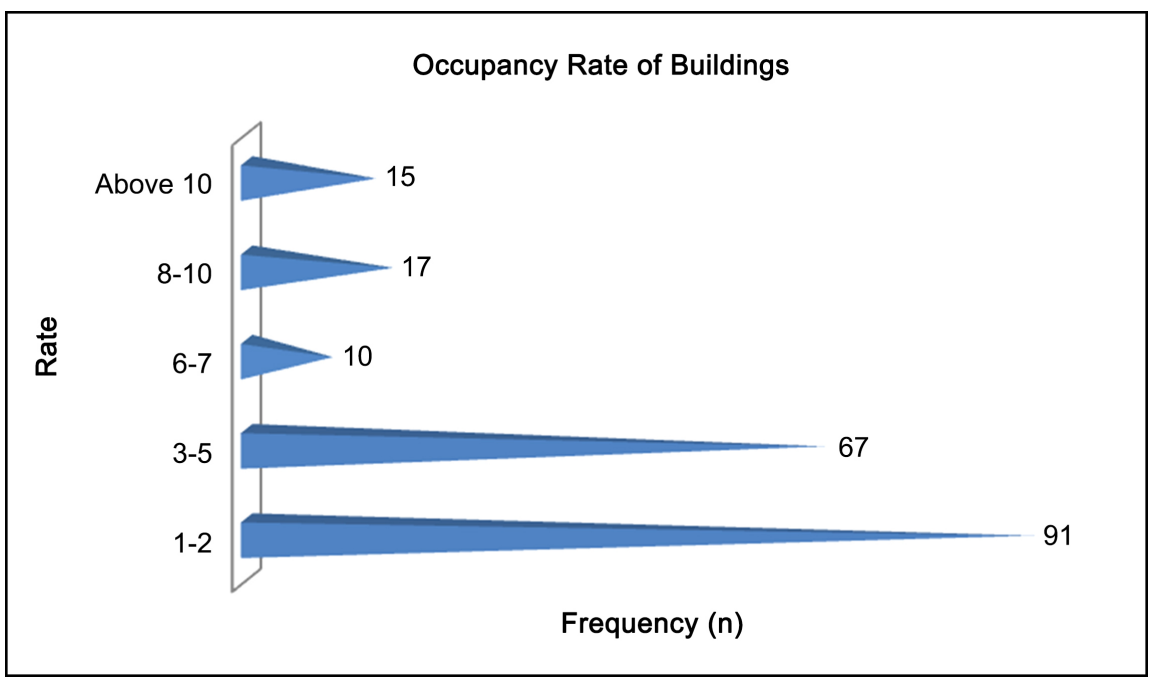

Figure 3. Occupancy rate of buildings (Source: Field Survey, 2020). 
Results of the study revealed that in a day, users of buildings in the Sunyani municipality spent about $7-9$ hours in these buildings whether residential or commercial (Table 2). This was followed by $4-6$ hours (29.0\%), $1-3$ hours (21.5\%), $10-12$ hours (10.5\%) and the least of $8.5 \%$ of respondents spending above 12 hours in these buildings daily.

The study indicated that buildings in the municipality used both natural and mechanical ventilation systems (Figure 4). It was revealed that majority of the buildings used a hybrid of natural and mechanical system accounting for $62.0 \%$. Natural ventilation represented $28.5 \%$ while the remaining $9.5 \%$ used mechanical ventilation systems.

A number of natural and mechanical ventilation systems were identified as used by various buildings in the municipality. With respect to natural ventilation, $45.5 \%$ used glassed louvre windows, followed by glaze sliding windows (31.5\%), open air windows (17.5) and wooden louvres accounting for 5.5\%. With respect to mechanical mechanical systems used, it was revealed that only fans were widely used in various facilities whether residential or commercial. This accounted for $43.5 \%$ of the type of mechanical system used in the municipality. A hybrid of fan and aircondition was next with $36.5 \%$ and the least of $20.0 \%$ was recorded by air condition only. This is shown in Table 3 below.

Table 2. Time spent in buildings daily by Respondents.

\begin{tabular}{ccc}
\hline Duration & Frequency (n) & Percentage of Frequency (\%) \\
\hline $1-3$ hours & 43 & 21.5 \\
$4-6$ hours & 58 & 29.0 \\
$7-9$ hours & 61 & 30.5 \\
$10-12$ hours & 21 & 10.5 \\
Above 12 hours & 17 & 8.5 \\
Total & 200 & 100.0 \\
\hline
\end{tabular}

Source: Field Survey, 2020.

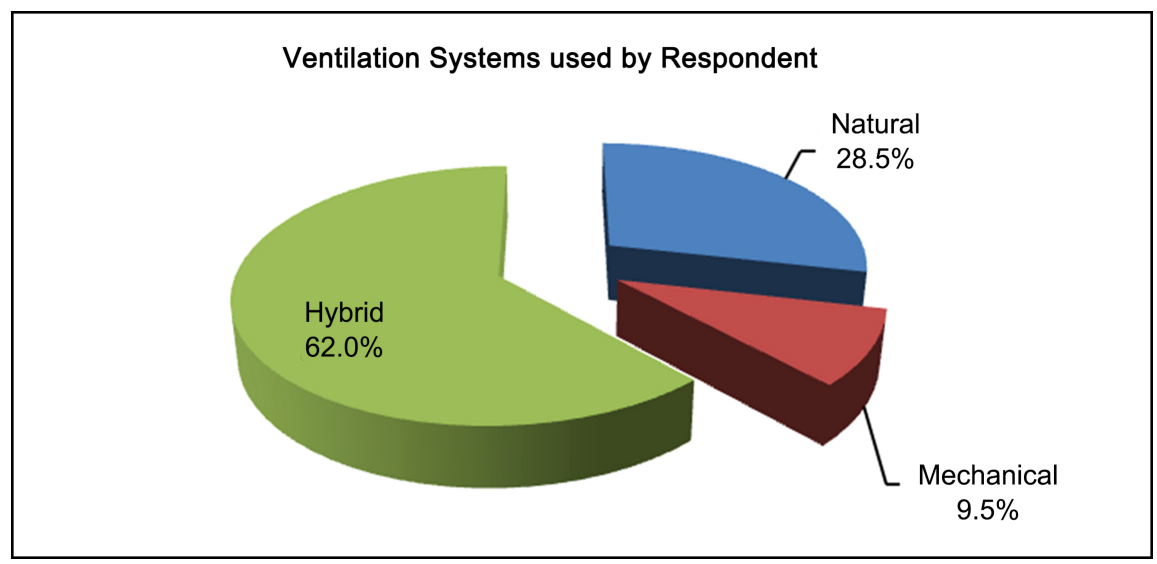

Figure 4. Ventilation systems used by respondent (Source: Field Survey, 2020). 
An assessment of the number of exits in the rooms occupied by respondents indicated that most of the rooms had 2 exits which consist of a doorway and one window (Figure 5). This accounted for $31.0 \%$ of the responses. This was followed by rooms with 3 exits consisting of a door way and two windows representing 29.5\%, 4 exits consisting of two doorways and two windows representing $18.0 \%, 5$ exits with two doorways and three windows (10.5\%) with the least of more than 5 exits with two doorways and more than three windows and 1 exit of a doorway only accounting for $5.5 \%$ each.

The study sought to investigate the type of material used for the construction of the rooms or buildings used by residents of the Sunyani municipality. The results as shown in Figure 6 indicated that $66.5 \%$ were constructed with sandcrete blocks, followed by clay bricks (14.5\%), glass $(8.5 \%)$, others $(3.5 \%)$, plastic (3.0\%), wood $(2.5 \%)$, and metal $(1.5 \%)$ respectively.

Table 3. Type of ventilation systems used by buildings.

\begin{tabular}{cccccc}
\hline \multicolumn{2}{c}{ Natural Ventilation } & \multicolumn{2}{c}{ Mechanical Ventilation } \\
\hline $\begin{array}{c}\text { Type of } \\
\text { Ventilation }\end{array}$ & $\begin{array}{c}\text { Frequency } \\
(\mathrm{n})\end{array}$ & $\begin{array}{c}\text { Percentage of } \\
\text { frequency } \\
(\%)\end{array}$ & $\begin{array}{c}\text { Type of } \\
\text { Ventilation }\end{array}$ & $\begin{array}{c}\text { Frequency } \\
(\mathrm{n})\end{array}$ & $\begin{array}{c}\text { Percentage of } \\
\text { frequency } \\
(\%)\end{array}$ \\
\hline Glaze Sliding & 63 & 31.5 & Fan only & 87 & 43.5 \\
Glass louvers & 91 & 45.5 & Air condition only & 40 & 20.0 \\
Wooden louvers & 11 & 5.5 & Fan \& Air condition & 73 & 36.5 \\
Open air window & 35 & 17.5 & Total & 200 & 100.0 \\
Total & 200 & 100.0 & & &
\end{tabular}

Source: Field Survey, 2020.

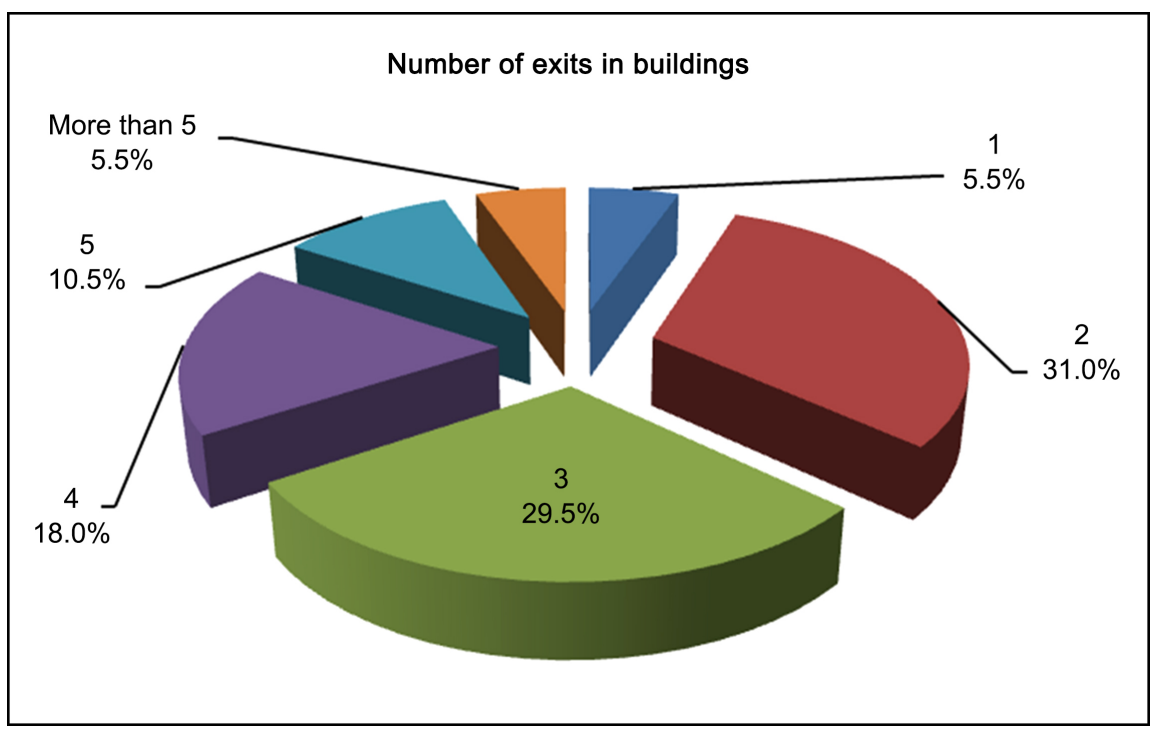

Figure 5. Number of exits in buildings (Source: Field Survey, 2020). 


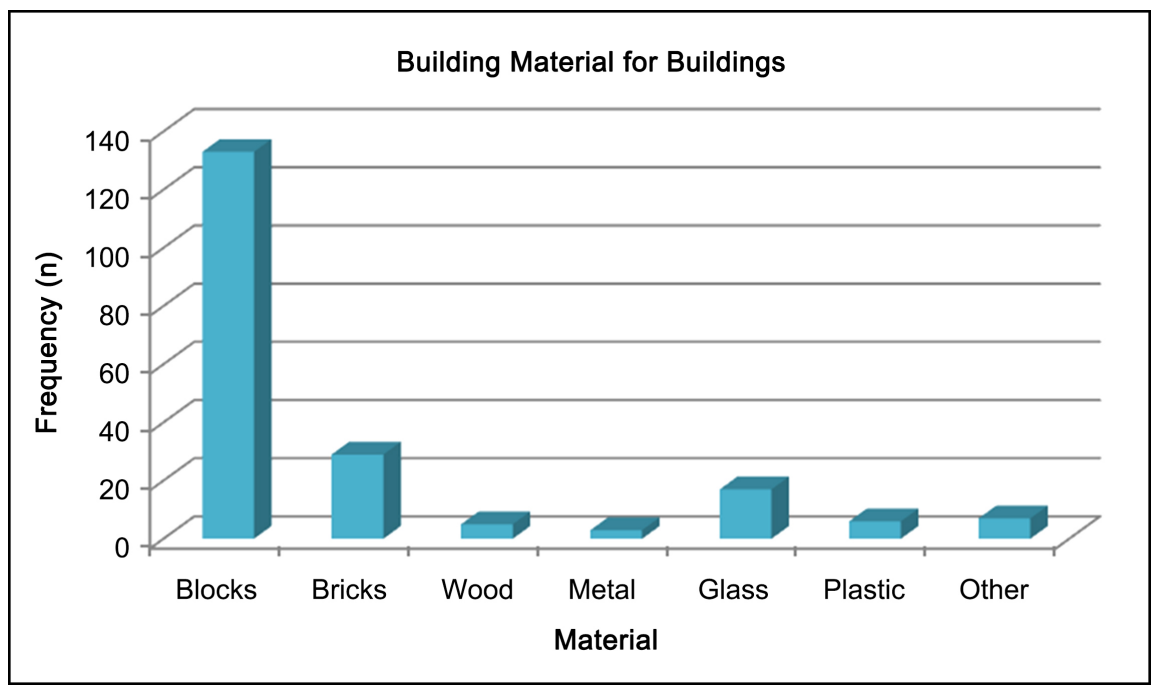

Figure 6. Type of material used for construction of building (Source: Field Survey, 2020).

It was revealed that $81.5 \%$ of the buildings were non storey while the remaining $18.5 \%$ were storey buildings. Out of this number of storey buildings, majority (68.0\%) were $1-2$ storey, $24.0 \%$ being $3-4$ storey and the least of $8.0 \%$ being 5 - 6 storey.

The study revealed that $89.0 \%$ of the rooms occupied by respondents were ceiled with the remaining $11.0 \%$ not ceiled. An evaluation of the ceiling materials used revealed that plywood dominated the materials used (Table 4). It accounted for $40.4 \%$ of the responses followed by plastic T \& J material (26.4\%), wooden T \& J (18.5\%), POP (7.3\%), plaster board (5.1\%), plastic sheet (1.7\%) and others aside the aforementioned $(0.6 \%)$ respectively.

The height of the ceiling of the rooms occupied by respondents revealed that majority (31.5\%) of them were about $11 \mathrm{ft}$ high (Figure 7). This was followed by those about $10 \mathrm{ft}$. (18.5\%), $8 \mathrm{ft}$. (15.7\%), above $11 \mathrm{ft} .(15.6 \%), 9 \mathrm{ft}$. (12.9\%) and less than $8 \mathrm{ft}$. representing $6.7 \%$ in that order.

\subsubsection{Infectious Disease Risks Associated with Ventilation Designs of Buildings in Ghana}

To investigate the effect of the ventilation design on the incidence of infectious diseases, the study examined the length of occupancy of the building by the respondents to ascertain the effects of the conditions in the buildings on the occurrence or experience of infectious disease conditions. The study results indicated that majority of the respondents (30.5\%) had used their current rooms for $4-5$ years (Figure 8). This was followed by those who had used the facility for $1-3$ years (28.0\%), 9 - 10 years (16.5\%), less than 1 year (13.5\%), 6 - 8 years $(9.5 \%)$ and more than 10 years in that order.

An investigation of the history of infectious diseases of occupants of buildings in the Sunyani municipality revealed that $55.5 \%$ of them had no history of any infectious disease with the remaining $44.5 \%$ reporting of having contracted infectious disease(s) sometime in over the past 10 years (Figure 9). 
Table 4. Ceiling materials for buildings.

\begin{tabular}{ccc}
\hline Ceiling Material & Frequency (n) & Percentage Frequency (\%) \\
\hline Plastic T \& J & 47 & 26.4 \\
Plywood & 72 & 40.4 \\
Wooden T \& J & 33 & 18.5 \\
POP & 13 & 7.3 \\
Plaster board & 9 & 5.1 \\
Plastic sheet & 3 & 1.7 \\
Other & 1 & 0.6 \\
Total & 178 & 100.0 \\
\hline
\end{tabular}

Source: Field Survey, 2020.

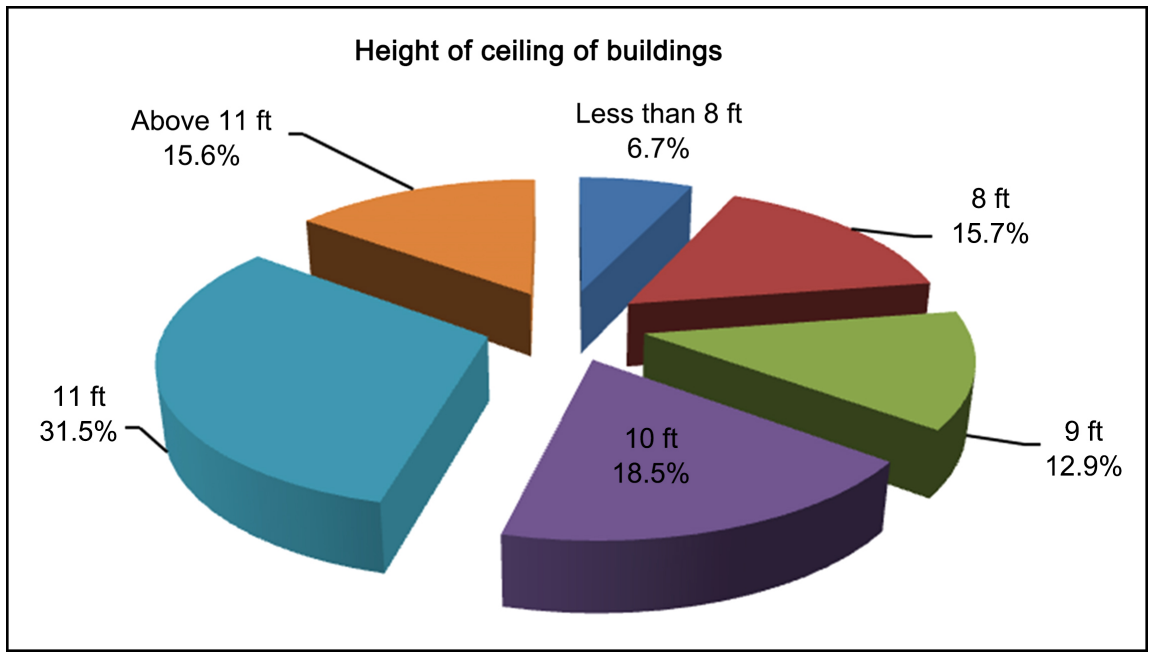

Figure 7. Height of ceiling of buildings (Source: Field Survey, 2020).

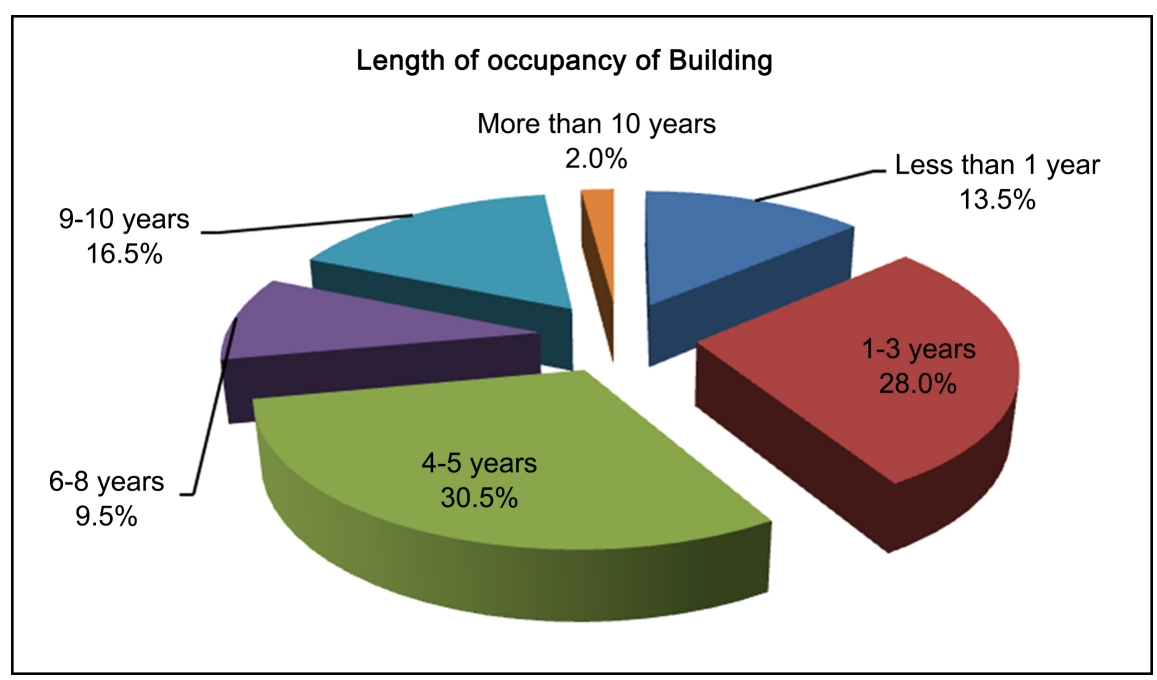

Figure 8. Length of occupancy of buildings (Source: Field Survey, 2020). 


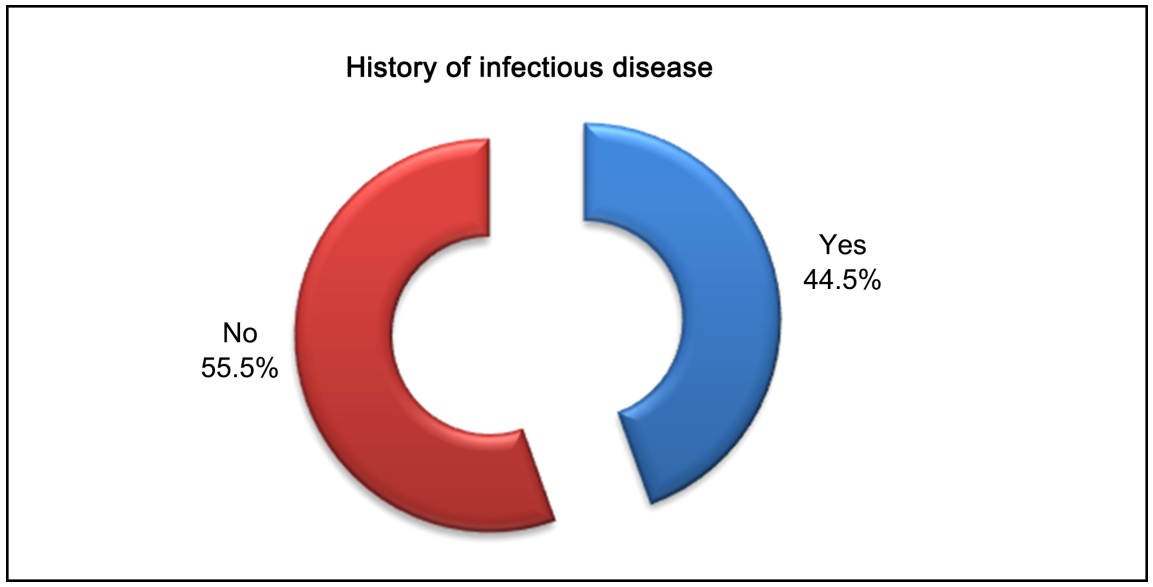

Figure 9. History of infectious disease(s) (Source: Field Survey, 2020).

Assessing the experience in condition in the buildings occupied by respondents revealed that most of the rooms were hot (Table 5). That is, about $37.0 \%$ of respondents noted that the condition of the rooms was too hot. About 24.5\% also reported of too humid conditions, followed by $15.5 \%$ reporting of too cold conditions, too dry (13.5\%), too stale (5.5\%) and drafty (4.0\%) respectively.

\subsubsection{Effects of Ventilation Design on the Incidence and Transmission of Infectious Diseases}

Responding to a question on whether they experienced any health conditions that may have been as a result of the conditions experienced in their room environment, majority (68.5\%) of the responses were in the negative (Figure 10). This is against $31.5 \%$ who responded that they had conditions as a result of their association in that environment as represented in Figure 9 above.

In a follow up question to those who experienced health conditions they linked to the conditions of their internal environment on whether others in same envioronment experienced same or related health conditions, majority (73.0\%) responded Yes. This is indicated in Figure 11 below.

An assessment of the duration or last of these health conditions or symptoms related to poor internal conditions of the rooms of occupation revealed that most of them had experienced it in the past 1 - 6 months (Table 6). This response represented $44.6 \%$, followed by 7 - 12 months (16.9\%), 13 - 18 months (13.3\%), 19 - 24 months (12.0\%), more than 24 months (8.4\%) and less than 1 month (4.8\%) respectively.

It was realized from the data collected that respondents experienced their worst symptoms of disease conditions mostly in the afternoon when the temperature is relatively high. Those who experienced worst symptoms in the afternoon accounted for $38.6 \%$ followed by evening (22.9\%), night (15.7\%), and morning (13.3\%) with the least of $9.6 \%$ experiencing it throughout the day (Figure 12).

The study results showed that majority of the respondents (61.4\%) indicated that their symptoms diminished or go away when they are out of that indoor environment. The opposite was the case for the remaining 38.6\% (Figure 13). 
Table 5. Experience in buildings by respondents.

\begin{tabular}{ccc}
\hline Experience & Frequency $(\mathbf{n})$ & Percent Frequency (\%) \\
\hline Too hot & 74 & 37.0 \\
Too cold & 31 & 15.5 \\
Too humid & 49 & 24.5 \\
Too dry & 27 & 13.5 \\
Drafty & 8 & 4.0 \\
Too stale & 11 & 5.5 \\
Total & 200 & 100.0 \\
\hline
\end{tabular}

Source: Field Survey, 2020.

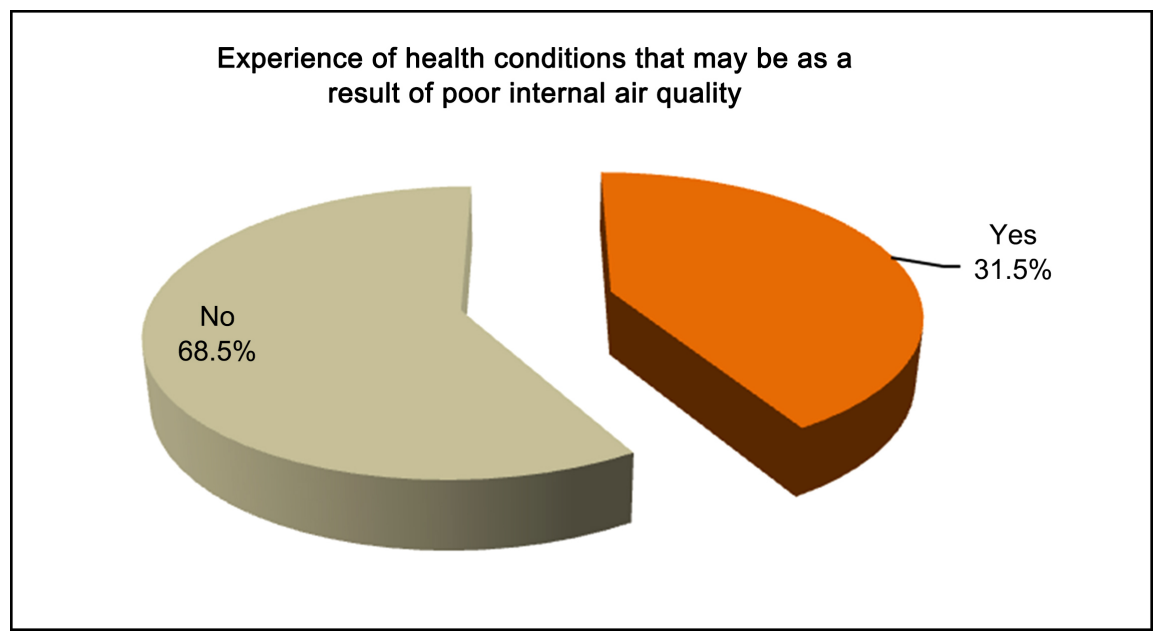

Figure 10. Response on heath conditions associated with room conditions. (Source: Field Survey, 2020).

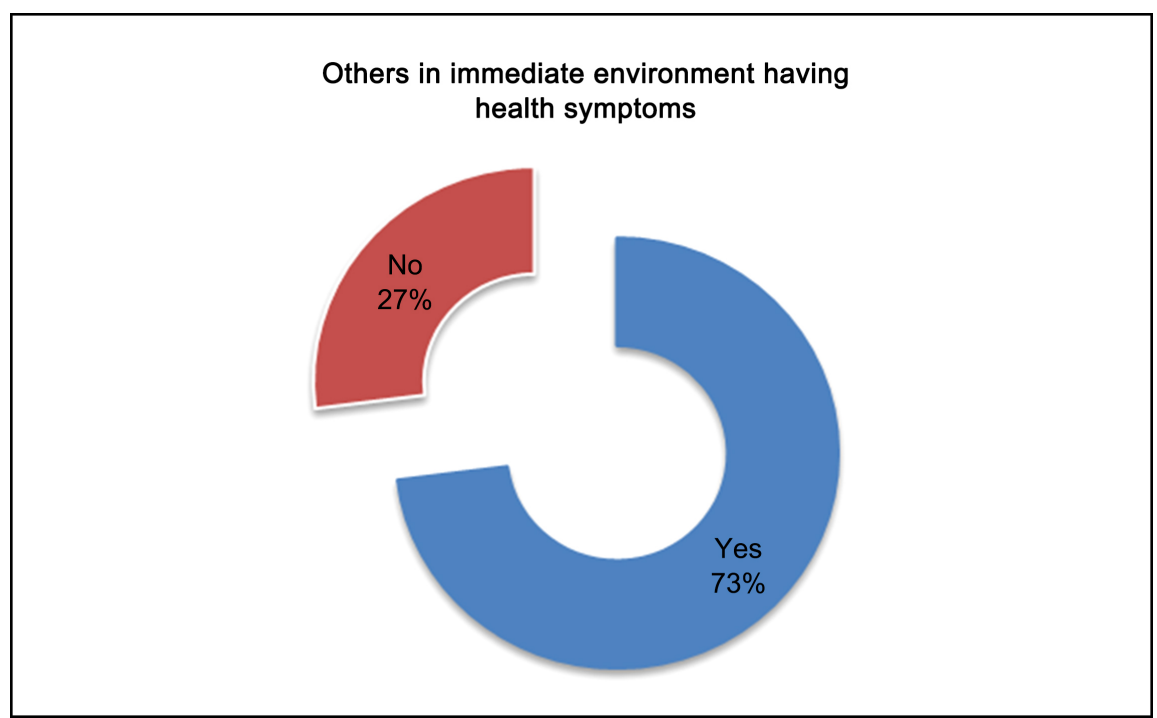

Figure 11. Respondents on whether others experienced health symptoms. (Source: Field Survey, 2020). 
Table 6. Duration of health conditions or symptoms related to poor internal condition.

\begin{tabular}{ccc}
\hline Duration & Frequency (n) & Percentage Frequency (\%) \\
\hline Less than 1 month & 4 & 4.8 \\
$1-6$ months & 37 & 44.6 \\
$7-12$ months & 14 & 16.9 \\
$13-18$ months & 11 & 13.3 \\
$19-24$ months & 10 & 12.0 \\
More than 24 months & 7 & 8.4 \\
Total & 83 & 100.0
\end{tabular}

Source: Field Survey, 2020.

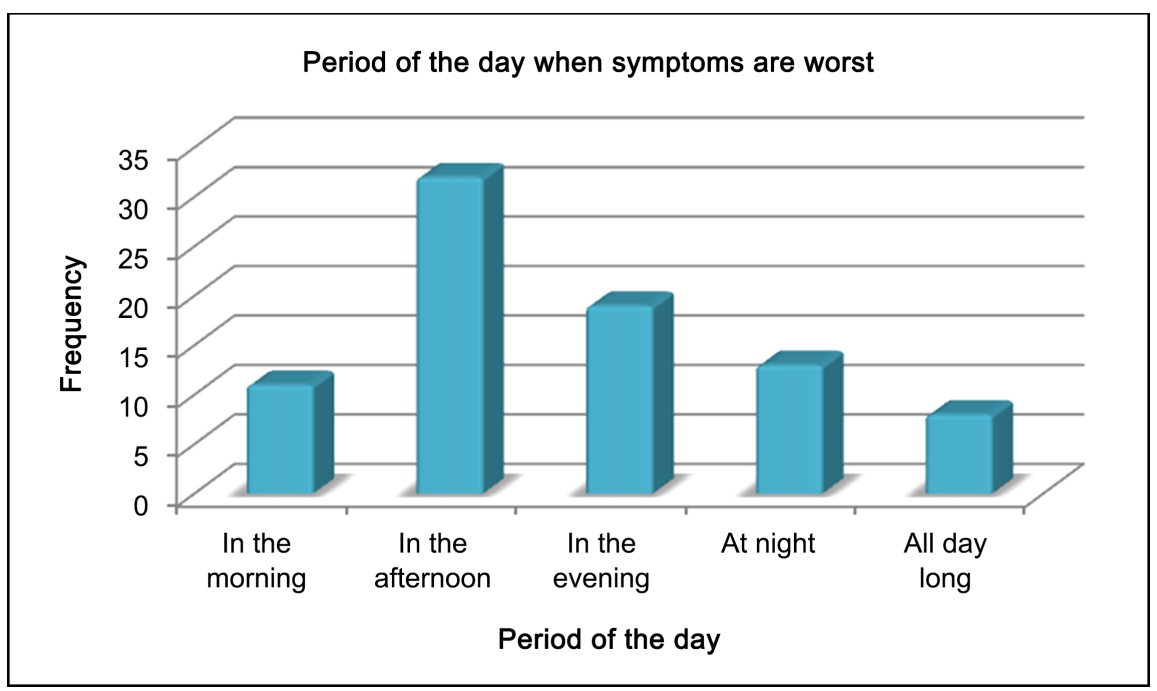

Figure 12. Period of the day when respondents experienced their worst symptoms (Source: Field Survey, 2020).

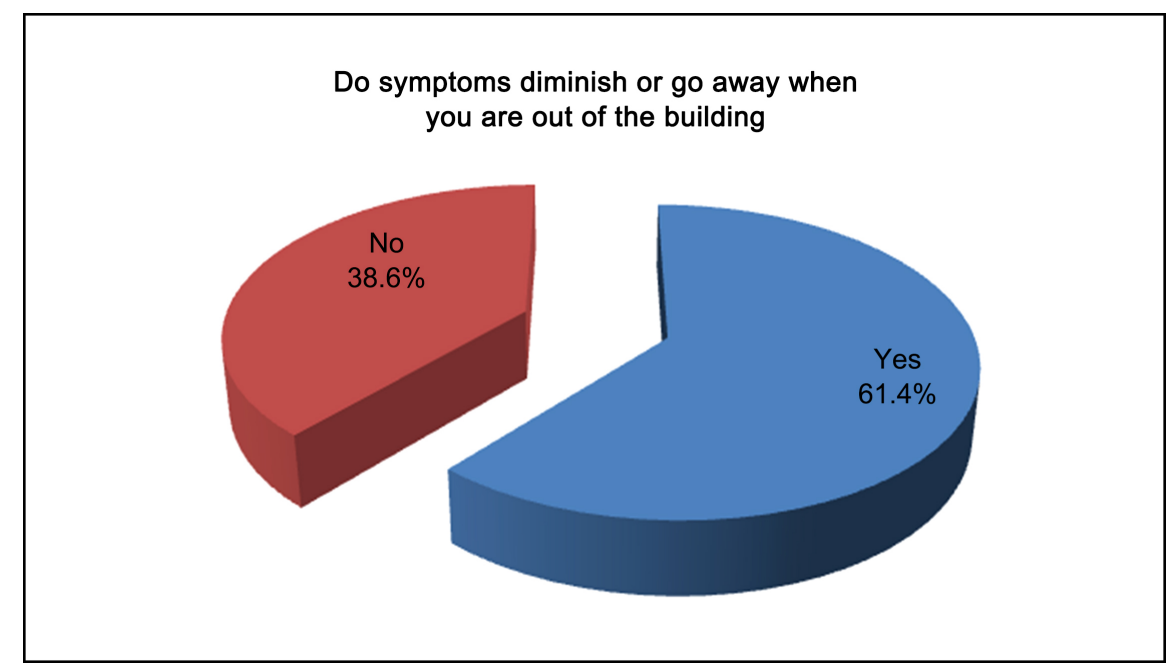

Figure 13. Respondents on whether symptoms diminished when they are out of the building environment (Source: Field Survey, 2020). 


\subsection{Discussion of Findings}

The study found that the hybrid ventilation system was widely used by residents of the Sunyani municipality. It was observed from the study that a greater number of respondents used fans and/or air conditions in addition to their glazed or open windows (natural ventilation) depending on whether the facility is for residential or commercial purposes. This observation goes to confirm the findings of Kleiven [35] that ventilation systems relying exclusively on natural driving forces will normally not be able to provide the desired airflow rate all the time. That is, they may not be sufficient on hot seasonal days without wind.

Moreover, the use of natural ventilation systems only was over the use of mechanical system only which could be attributed to the cost considerations. This ventilation system applied ensures the supply of fresh air and sunlight into the buildings. Chronological and recent studies suggest that natural and/or hybrid ventilation offers protection from transmission of airborne pathogens through dispersal by fresh air and a boost of resistance to infection by sunlight. This assertion is backed by Brown [36] who reported that sick building syndrome (SBS) is more common in mechanically ventilated buildings than in naturally ventilated ones. This is because mechanical ventilation systems and their components themselves have been designated as significant pollution sources.

Again, the study revealed that many of the building designs ensured adequate circulation of air due to their high ceilings. These combined could be an effective way of preventing or reducing the risk of transmission of infectious diseases within that space. This assertion is corroborated by Hobday and Dancer [11] who opined that many ventilation designs of buildings were fitted with glazing, cross-ventilation and high ceilings because fresh air and sunlight were thought to reduce infection risk. Also, Edwards [8] supports this finding that well designed natural ventilated buildings can provide higher air change rates than poorly designed poorly designed natural or mechanical ventilated buildings. Poorly designed or maintained mechanically ventilated buildings have been associated with sick building syndrome and can potentially be eliminated in naturally ventilated buildings. This finding however does not support the argument by Rintala et al. [37] which suggests that there is no evidence that mechanical ventilation has facilitated the spread of infection in houses, although a wide range of micro-organisms, including pathogens, may be found indoors.

Indoor conditions of a building or room could encourage the growth and development of disease causing organisms that could lead to infection of its occupants. The study results indicated that majority of buildings experienced very hot internal temperatures. The higher temperatures experienced in most part of the day in buildings could be attributed to relatively low number of exits in most buildings, the length of time of occupancy, rate of occupancy, height and celing and ceiling materials used. The Sunyani municipality generally experiences tropical conditions and therefore with such too hot internal condition the humid starts to condense on the thermal bridges of the envelope of the building which 
leads to microbial growth and development. This means that prolonged exposure to these microbes could be a predisposing factor for infectious diseases within that indoor environment. This could also be the reason why majority of occupants of these buildings experience their worst symptoms when they are within the environment of the buildings. This observation is supported by the position of the EU [38] report on ventilation system and possibilities to use regulated ventilation in historic buildings which indicated that the disparity of high indoor temperature and low outdoor temperature leads to condensation (which occurs when warm, moist air from inside a building penetrates a wall, roof or floor and meets a cold surface) which becomes a major threat to the structure of the building, and this high relative humidity in over a long period creates a very favourable environment for various microbes, mold and bacteria spread.

\section{Conclusions and Recommendations}

\subsection{Conclusions}

Ghana has a well-documented building code DGS 1207: 2018. However, it was found that this regulation was not used by majority of building owners and builders (including masons, engineers etc.) alike. Majority of these technical men interviewed indicated that though the code existed, it was not applicable in most residential and commercial facilities. This is because these structures are constructed without permit and/or regulation by the appropriate regulatory and/or supervisory institutions. Such permits could only be granted if the necessary guidelines with respect to ventilation design of the project meet acceptable standard for the specific project. This has resulted in a number of illegal construction, modification and utilization of buildings for purposes for which they were not originally designed for. The study concludes that the designs of structures in the Sunyani Municipality somewhat ensure ventilation of the said buildings. It was observed that majority of buildings with poor ventilation designs were as a result of change in the intended use of the building as designed. That is, most of the commercial buildings for shops, stores and small scale enterprises had been converted from residential to commercial purposes thus changing the structural and fitting design, occupancy rate, length of occupancy, rate of flow of air among others which are predisposing factors for poor ventilation and its attendant health conditions. This is against the backdrop of several suggestions that low ventilation rates are associated with increased infection rates or outbreaks of airborne diseases.

With the findings of this study, it was revealed that sick building syndrome was common among respondents who occupied especially residential facilities. This could be a basis for asserting that it occurs from the conditions in the building's indoor environment which could intend to be a influencing factor for transmission of some infectious diseases. However, the study could not establish whether the symptoms experienced by respondents could solely be as a result of 
the poorly ventilated space or a predisposing factor transmission. There is little evidence that ventilation directly reduces the risk of disease transmission. Poor ventilation and indoor air quality which may lead to pathogens in room air and buildings may suggest a possible, indirect link between ventilation and disease transmissions. However, other aspects (e.g. necessary infecting dose, susceptibility of the host, infectivity of the pathogen, other environmental factors) are important for determining the ability of a pathogen to be transmitted from one occupant of the building to the other. Therefore, data on ventilation design of buildings does not provide the full evidence for disease transmission, and should be used in conjunction with other data.

\subsection{Recommendations}

1) There should be strict enforcement of the application or use of the Ghana's Building Code or Regulation in the design and construction of all structures that ensure adequate ventilation for buildings for specific purposes.

2) There should be conscious efforts by regulatory authorities to ensure that buildings are designed to encourage the use of natural ventilation systems as much as possible.

3) The building use with its requirements and potentials must be thorough examined and understood by the designers both to clarify the applicability of natural ventilation in the first place and to utilize the potential of the natural driving forces as effectively as possible in case of modification or change of use.

4) Further studies should be conducted on the relationship between indoor and outdoor environmental conditions and the buildings ventilation design and how they impact on transmission of diseases.

\section{Conflicts of Interest}

The authors declare no conflicts of interest regarding the publication of this paper.

\section{References}

[1] Leech, J.A., Nelson, W.C., Burnett, R.T., Aaron, S. and Raizenne, M.E. (2002) It's about Time: A Comparison of Canadian and American Time-Activity Patterns. Journal of Exposure Analysis and Environmental Epidemiology, 12, 427-432. https://doi.org/10.1038/sj.jea.7500244

[2] Tronchin, L., Fabbri, K. and Bertolli, C. (2018) Controlled Mechanical Ventilation in Buildings: A Comparison between Energy Use and Primary Energy among Twenty Different Devices. Energies, MDPI, Open Access Journal, 11, 1-19. https://doi.org/10.3390/en11082123

[3] Gao, X., Wei, J., Lei, H., Xu, P., Cowling, B.J. and Li, Y. (2016) Building Ventilation as an Effective Disease Intervention Strategy in a Dense Indoor Contact Network in an Ideal City. PLoS ONE, 11, e0162481. https://doi.org/10.1371/journal.pone.0162481

[4] Awbi, H. (2003) Ventilation of Buildings. Spon Press, Taylor and Francis Group, Abingdon-on-Thames. https://doi.org/10.4324/9780203634479 
[5] Khaleghi, A., Bartlett, K. and Hodgson, M. (2011) Factors Affecting Ventilation, Indoor-Air Quality and Acoustical Quality in "Green" and Non-"Green” Buildings: A Pilot Study. Journal of Green Building, 6, 168-180. https://doi.org/10.3992/jgb.6.3.168

[6] Jenkins, M. (2019) Stack Effect and Ventilation System Design. https://www.simscale.com/blog

[7] Escombe, A.R., Ticona, E., Chávez-Pérez, V., Espinoza, M. and Moore, D.A. (2019) Improving Natural Ventilation in Hospital Waiting and Consulting Rooms to Reduce Nosocomial Tuberculosis Transmission Risk in a Low Resource Setting. BMC Infectious Diseases, 19, 88. https://doi.org/10.1186/s12879-019-3717-9

[8] Edwards, C. (2000) Design Rules of Thumb for Naturally Ventilated Office Buildings in Canada. Master of Advance Studies in Architecture Thesis, University of British Columbi, Vancouver.

[9] Lateef, F. (2009) Hospital Design for Better Infection Control. Journal of Emergencies, Trauma, and Shock, 2, 175-179. https://doi.org/10.4103/0974-2700.55329

[10] Ishak, S.N., Chohan, A.H. and Ahmad, R. (2007) Implications of Design Deficiency on Building Maintenance at Post-Occupational Stage. Journal of Building Appraisal, 3, 115-124. https://doi.org/10.1057/palgrave.jba.2950061

[11] Hobday, R. and Dancer, S.J. (2013) Roles of Sunlight and Natural Ventilation for Controlling Infection: Historical and Current Perspectives. Journal of Hospital Infection, 84, 271-282. https://doi.org/10.1016/j.jhin.2013.04.011

[12] Reshetniak, E. (2014) Mechanical Supply and Exhaust Ventilation in Residential Building. MAMK University of Applied Sciences: Bachelor Thesis Double Degree Program in Building Services Engineering.

[13] Commission for Occupational Safety and Health (2008) Code of Practice Safe Design of Buildings and Structures. Australia: State Law.

[14] Memarzadeh, F. (2013) Literature Review: Room Ventilation and Airborne Disease Transmission. The American Society for Healthcare Engineering (ASHE) and the Facility Guidelines Institute, Chicago, Dallas.

[15] ASHRAE (2005) Fundamentals Handbook, Ch. 7 Sound and Vibration Control. American Society of Heating, Refrigeration and Air-Conditioning Engineers, Atlanta.

[16] de Gids, W.F. and Jicha, M. (2010) Ventilation Information Paper 32: Hybrid Ventilation Archived 2015-11-17 at the Wayback Machine. Air Infiltration and Ventilation Centre (AIVC).

[17] Walker, A. (2016) Natural Ventilation. National Institute of Building Sciences, Washington DC.

[18] Rajkumar, G. (n.d.) Causes and Effects Of Poor Indoor Air Quality. Caribbean Industrial Research Institute (CARIRI), Macoya.

[19] IPCC (2014) Climate Change 2014: Synthesis Report. In: Pachauri, R.K. and Meyer, L.A., Eds., Contribution of Working Groups I, II and III to the Fifth Assessment Report of the Intergovernmental Panel on Climate Change, IPCC, Geneva, 1-115.

[20] Zimring, C., Anjali, J., Nicoll, G.L. and Tsepas, S. (2005) Influences of Building Design and Site Design on Physical Activity-Research and Intervention Opportunities. American Journal of Preventive Medicine, 28, 186-193.

https://doi.org/10.1016/j.amepre.2004.10.025

[21] Chenvidyakarn, T. (2013) Buoyancy Effects on Natural Ventilation. Cambridge University Press, Cambridge. https://doi.org/10.1017/CBO9781139058407 
[22] Balaras, C.A. (2003) Mechanical Ventilation and Equipment. In: Balaras, C.A., Ed., Air Conditioning-Energy Consumption and Environmental Quality-Mechanical Ventilation and Encyclopedia of Life Support Systems (EOLSS), UNESCO-EOLSS, Paris, 1-10.

[23] NASA (2011) Global Warming vs. Climate Change. NASA.

[24] American Society of Heating, Refrigerating and Air-Conditioning Engineers, Inc. (ASHRAE) (2009) Airborne Infectious Diseases. American Society of Heating, Refrigerating and Air-Conditioning Engineers, Inc., Atlanta.

[25] Xie, X., Li, Y., Chwang, A.T.Y., Ho, P.L. and Seto, H. (2007) How Far Droplets Can Move in Indoor Environments-Revisiting the Wells Evaporation-Falling Curve. Indoor Air, 17, 211-225. https://doi.org/10.1111/j.1600-0668.2007.00469.x

[26] World Health Organization (WHO) (2009) Natural Ventilation for Infection Control in Health-Care Settings. World Health Organization Press, Geneva.

[27] DH (2006) Health Technical Memorandum 07-02: EnCO2de: Making Energy Work in Healthcare, Environment and Sustainability. Department of Health Estates and Facilities Division, The Stationary Office.

[28] Center for Disease Control and Prevention (CDC) (2001) Recognition of Illness Associated with the Intentional Release of a Biologic Agent. Journal of the American Medical Association, 286, 2088-2090.

https://doi.org/10.1001/jama.286.17.2088-JWR1107-2-1

[29] Li, Y., Leung, G.M., Tang, J.W., Yang, X., Chao, C.Y.H., Lin, J.Z., Lu, J.W., Nielsen, P.V., Niu, J., Qian, H., Sleigh, A.C., Su, H.-J.J., Sundell, J., Wong, T.W. and Yuen, P.L. (2007) Role of Ventilation in Airborne Transmission of Infectious Agents in the Built Environment-A Multidisciplinary Systematic Review. Indoor Air, 17, 2-18. https://doi.org/10.1111/j.1600-0668.2006.00445.x

[30] Center for Disease Control and Prevention (CDC) (2005) Guidelines for Preventing the Transmission of Mycobacterium Tuberculosis in Health-Care Settings. Morbidity and Mortality Weekly Report (MMWR), 54, 1-140.

[31] American Institute of Architects (AIA) (2006) Guidelines for Design and Construction of Health Care Facilities: 2006 Edition. AIA, Washington DC. http://www.aia.org

[32] Spengler, J.D., Samet, J.M. and McCarthy, J.F. (2001) Indoor Air Quality Handbook. McGraw-Hill Education, New York.

[33] World Health Organization (2001) Occupational Health-A Manual for Primary Health Care Workers. Regional Office for the Eastern Mediterranean, Cairo.

[34] Memarzadeh, F. and Xu, W. (2012) Role of Air Changes per Hour (ACH) in Possible Transmission of Airborne Infections. Building Simulation, 5, 15-28. https://doi.org/10.1007/s12273-011-0053-4

[35] Kleiven, T. (2003) Natural Ventilation in Buildings: Architectural Concepts, Consequences and Possibilities. Norwegian University of Science and Technology, Trondheim.

[36] Brown, D.J. (2000) The Arup Journal (Millennium Issue 3), Vol. 35 No. 2, Ove Arup Partnership Ltd., London.

[37] Rintala, H., Pitkaranta, M., Toivola, M., Paulin, L. and Nevalainen, A. (2008) Diversity and Seasonal Dynamics of Bacterial Community in Indoor Environment. BMC Microbiology, 8, 56. https://doi.org/10.1186/1471-2180-8-56

[38] European Union (2013) Ventilation System. Baltic Sea Region Programme: WP5 Education and Economic Promotion. 